\title{
ANTI-INFLAMMATORY PROFILING OF SEED AND RIND EXTRACTS OF AMOMUM SUBULATUM
}

\section{SUPRIYA AGNIHOTRI}

Department of Pharmacognosy, Chandigarh College of Pharmacy, Landran, Mohali. Email: asupriya149@gmail.com

\author{
Received: 01 March 2020, Revised and Accepted: 20 April 2020
}

\begin{abstract}
Objective: The study aimed to evaluate the anti-inflammatory activity of Amomum subulatum (greater cardamom) seed and rind extracts in Wistar rats.

Methods: The seed and rind of $A$. subulatum were air-dried in the shade, powdered, and subjected to $80 \%$ hydroalcoholic extraction in the Soxhlet apparatus. The anti-inflammatory activity of the seed and rind extracts of $A$. subulatum was evaluated by in vivo and in vitro methods.

Results and Discussion: In vivo studies, namely, carrageenan-induced rat paw edema, cotton pellet granuloma, and formaldehyde-induced arthritis model confirmed the anti-inflammatory potential of seed and rind extracts of $A$. subulatum. It was found that rind extract exhibited better inhibition of inflammation as compared to seed extract. A. subulatum rind extract at the dose of $500 \mu \mathrm{g} / \mathrm{ml}$ exhibited best results for in vitro studies, namely, inhibition of albumin denaturation (73\% inhibition), antiproteinase action (58\% inhibition), membrane stabilization, heat-induced hemolysis, hypotonicity-induced hemolysis (54\% inhibition), anti-lipoxygenase activity.
\end{abstract}

Conclusions: The results of the study showed that the rind extract of A. subulatum (greater cardamom) possesses significant anti-inflammatory potential in various in vivo and in vitro anti-inflammatory models in the experimental animals.

Keywords: Amomum subulatum, Carrageenan, In vitro anti-inflammatory, Anti-lipoxygenase.

(C) 2020 The Authors. Published by Innovare Academic Sciences Pvt Ltd. This is an open access article under the CC BY license (http://creativecommons. org/licenses/by/4. 0/) DOI: http://dx.doi.org/10.22159/ajpcr.2020.v13i6.37625

\section{INTRODUCTION}

Amomum subulatum Roxb., commonly known as greater cardamom belonging to the family Zingiberaceae, is an evergreen herb native to Eastern Himalayas, near mountain streams in Darjeeling, Sikkim, and Northeast India [1]

The major chemical constituent of the herb is 1,8-Cineole. Other minor constituents include sabinene, $\gamma$-terpinene, $\alpha$-bisabolene, $\alpha$-terpinyl acetate, $\alpha$ - and $\beta$-terpineol, cinnamaldehyde, linalool, cuminaldehyde, terpinene-4-ol, petunidin protocatechualdehyde, protocatechuic acid, 1, 7-bis(3,4-dihydroxyphenyl) hepta-4E, 6E-dien-3-one, and 2,3,7-trihydroxy-5-(3,4-dihydroxy-E-styryl)-6,7,8,9-tetrahydro-5Hbenzocycloheptene. Other isolated constituents include cardamonin and alpinetin; the glycosides petunidin 3,5-diglucoside (C28H33017), leucocynidin-3-0- $\beta$-D-glucopyranoside (C21H24012); a new aurone glycoside, subulin (C28H32016); chalcone, cardamonin (C16H1404) and a flavanone, alpinetin. A seed of the plant shows the presence of cardamonin and alpinetin [2-4] Fig. 1.

The herb is useful in congestion of liver; gonorrhea, neuralgia, headache, and stomatitis [5]. It also shows gastric anti-ulcerogenic effect [6], antioxidant activity [7], and antioxidant activity [8].

In the present studies, seeds and rind of the plant are evaluated for their in vivo and in vitro anti-inflammatory activity.

\section{METHODS}

Procurement and authentication of raw material

The fruits of $A$. subulatum were procured from the local market of Sunder Nagar, Dist. Mandi, Himachal Pradesh. The crude drug was authenticated by a senior botanist at National Bureau of Plant Genetic Resources, New Delhi (Voucher number: EP 532).

\section{Preparation of extracts}

The rinds and seeds (1000 g + $1500 \mathrm{~g}$ resp.) were coarsely powdered and extracted in a Soxhlet apparatus separately with $80 \%$ methanol for
$72 \mathrm{~h}$. The methanolic extracts were concentrated on a steam bath and dried under reduced pressure to get the brown-colored powder and kept in desiccators.

\section{Assessment of in vivo anti-inflammatory activity} Carrageenan-induced rat hind-paw edema method The effect of oral administration of 100,250 , and $500 \mathrm{mg} / \mathrm{kg}$ of the extracts of activity of the rind (ASR) and activity of the seed (ASS), $40 \mathrm{mg} / \mathrm{kg}$ diclofenac and vehicle (saline, $10 \mathrm{ml} / \mathrm{kg}$ ) on the hindpaw edema induced by subplantar injection of $0.1 \mathrm{ml}$ carrageenan $(1 \% \mathrm{w} / \mathrm{v})$ was evaluated according to the method described by Winter et al. [9].

\section{Cotton pellet-induced granuloma method}

The method of Winter and Porter with minor revision was used to study chronic inflammation [7]. The animals were anesthetized with ether. The axillary skin was shaved and disinfected with $70 \%$ ethanol. An incision was made and by a blunt forceps subcutaneous tunnels were formed and a sterilized cotton pellet ( $50 \pm 1 \mathrm{mg}$ ) was placed in both axillas. The vehicle, test extracts (ASR and ASS) (100, 250, and $500 \mathrm{mg} / \mathrm{kg}$, p.o.), and standard (diclofenac) were administered for 7 consecutive days starting from the day of cotton implantation. On the $8^{\text {th }}$ day, rats were anesthetized again and the cotton pellet (along with granular tissue formed around) was removed surgically and freed from extraneous tissue. The pellets were weighed immediately for wet weight. Then, pellets were dried in an incubator at $60^{\circ} \mathrm{C}$ until a constant weight was obtained [10].

\section{Formaldehyde-induced arthritis assay}

In formaldehyde-induced arthritis models, animals were divided into groups as per treatment, namely, normal control, arthritic control, standard, ASR extract treated, and ASS extract treated. The test extracts were given for 10 days. Thirty minutes after administration of the vehicle/test extracts, arthritis was induced by subplantar administration of $0.1 \mathrm{ml}$ formaldehyde $(2 \% \mathrm{v} / \mathrm{v})$ into the left hind paw of all the animals on days 1 and 3 . An increase in 
joint diameter was measured on days $0,2,4,6,8$, and 10 as paw volume [11].

\section{Assessment of in vitro anti-inflammatory activity}

Inhibition of protein denaturation [12,13]

The in vivo anti-inflammatory activity of $A$. subulatum extracts (ASR and ASS) was studied using inhibition of albumin denaturation technique. The reaction mixture contained test extracts (ASR and ASS) and $1 \%$ aqueous solution of bovine albumin fraction, the $\mathrm{pH}$ of the reaction mixture was adjusted using a small amount of $1 \mathrm{~N}$ $\mathrm{HCl}$. The sample extracts were incubated at $37^{\circ} \mathrm{C}$ for $20 \mathrm{~min}$ and then heated to $51^{\circ} \mathrm{C}$ for $20 \mathrm{~min}$, after cooling the samples, the turbidity was measured at $660 \mathrm{~nm}$ (ultraviolet-visible spectrophotometer). The percentage inhibition of protein denaturation was calculated as follows:

$$
\text { Percentageinhibition }=\frac{(\text { Abscontrol }- \text { Abssample })}{\text { Abscontrol }} \times 100
$$

Antiproteinase action [13,14]

In this test, the reaction mixture $(2 \mathrm{ml})$ was containing $0.06 \mathrm{mg}$ trypsin, $1 \mathrm{ml} 20 \mathrm{mM}$ Tris-HCl buffer ( $\mathrm{pH}$ 7.4), and $1 \mathrm{ml}$ test extracts (ASR and ASS) of different concentrations $(100-500 \mu \mathrm{g} / \mathrm{ml})$. The mixture was incubated at $37^{\circ} \mathrm{C}$ for $5 \mathrm{~min}$ and then $1 \mathrm{ml}$ of $0.8 \%$ $(\mathrm{w} / \mathrm{v})$ casein was added. The mixture was incubated for an additional $20 \mathrm{~min}$. A $2 \mathrm{ml}$ of $70 \%$ perchloric acid was added to detain the reaction. Centrifugation of cloudy suspension was carried out and the absorbance of the supernatant was recorded at the wavelength $210 \mathrm{~nm}$ against buffer as blank. The experiment was performed in triplicate. The percentage inhibition of proteinase inhibitory activity was calculated.

$$
\text { Percentageinhibition }=\frac{(\text { Abscontrol }- \text { Abssample })}{\text { Abscontrol }} \times 100
$$

\section{Membrane stabilization}

For the preparation of red blood cells (RBCs) suspension [13,15], the blood was collected from healthy animals that were not involved in any type of anti-inflammatory studies at least for the last 3 weeks and transferred to the centrifuge tubes. Centrifugation of the tubes was carried out at the speed of $3000 \mathrm{rpm}$ for $10 \mathrm{~min}$ and then washing was carried out thrice with an equal volume of normal saline. The volume of blood was measured and reconstituted as a $10 \% \mathrm{v} / \mathrm{v}$ suspension with normal saline.

\section{Heat-induced hemolysis $[13,16]$}

The reaction mixture $(2 \mathrm{ml})$ consisted of $1 \mathrm{ml}$ test extracts (ASR and ASS) of different concentrations $(100-500 \mu \mathrm{g} / \mathrm{ml})$ and $1 \mathrm{ml}$ of $10 \%$ RBCs suspension, instead of test sample only saline was added to the control test tube. Aspirin was used as a standard drug. All the centrifuge tubes containing reaction mixture were incubated in a water bath at $56^{\circ} \mathrm{C}$ for $30 \mathrm{~min}$. At the end of the incubation, the tubes were cooled under running tap water. The reaction mixture was centrifuged at $2500 \mathrm{rpm}$ for $5 \mathrm{~min}$ and the absorbance of the supernatants was taken at $560 \mathrm{~nm}$. The experiment was performed in triplicates for all the test samples. The percentage inhibition of hemolysis was calculated as follows:

$$
\text { Percentageinhibition }=\frac{(\text { Abscontrol }- \text { Abssample })}{\text { Abscontrol }} \times 100
$$

\section{Hypotonicity-induced hemolysis [17]}

Different concentrations of test extract (ASR and ASS) $(100-500 \mu \mathrm{g} / \mathrm{ml}$ ), reference sample, and control were separately mixed with $1 \mathrm{ml}$ of phosphate buffer, $2 \mathrm{ml}$ of hyposaline, and $0.5 \mathrm{ml}$ of RBC suspension. For comparison with standard, diclofenac sodium $(100 \mu \mathrm{g} / \mathrm{ml})$ was used. All the assay mixtures were incubated at $37^{\circ} \mathrm{C}$ for $30 \mathrm{~min}$ and centrifuged at $3000 \mathrm{rpm}$. Hemoglobin was estimated by decanting the supernatant liquid and recording absorbance at $560 \mathrm{~nm}$. The percentage of hemolysis was estimated by assuming the hemolysis produced in the control as $100 \%$.

\section{Percentageprotection $=100-($ ODsample $/$ ODcontrol $) \times 100$}

\section{Anti-lipoxygenase activity [16]}

Anti-lipoxygenase activity was studied using linoleic acid as a substrate and lipoxidase as an enzyme. Test extracts (ASR and ASS) at different dose levels $(100-500 \mu \mathrm{g} / \mathrm{ml})$ were dissolved in $0.25 \mathrm{ml}$ of $2 \mathrm{M}$ borate buffer $\mathrm{pH} 9.0$ and added $0.25 \mathrm{ml}$ of lipoxidase enzyme solution $(20,000 \mathrm{U} / \mathrm{ml})$ and incubated for $5 \mathrm{~min}$ at $25^{\circ} \mathrm{C}$. Later, $1 \mathrm{ml}$ of linoleic acid solution $(0.6 \mathrm{mM})$ was added, mixed well and absorbance was measured at $234 \mathrm{~nm}$. Indomethacin was used as a reference standard. The percent inhibition was calculated from the following equation,

\section{\%inhibition $=[\{$ Abs control - Abssample $\} /$ Abs control $] \times 100$}

A dose-response curve was plotted to determine the $\mathrm{IC}_{50}$ values. $\mathrm{IC}_{50}$ is the concentration sufficient to obtain $50 \%$ of a maximum scavenging capacity. All tests and analyses were run in triplicate and averaged.

\section{Statistical analysis}

Results are expressed as Mean \pm SD. The difference between experimental groups was compared by one-way ANOVA followed by Dunnett's multiple comparison test (control vs. test) using the software GraphPad Instat.

\section{RESULTS AND DISCUSSION}

Effect of $A$. subulatum extracts on carrageenan-induced rat paw edema

About $80 \%$ methanolic extracts of rind and fruits of $A$. subulatum were studied for their acute anti-inflammatory activity on three dose levels, namely, low (100 mg/kg), medium (250 mg/kg), and high $(500 \mathrm{mg} / \mathrm{kg})$. Both the extracts were found to have anti-inflammatory activity. The \% inhibition was seen maximum in case of rind extract (500 mg/kg) treated animal group.

\section{Effect of $\boldsymbol{A}$. subulatum extracts on cotton pellet granuloma in rats} The cotton pellet granuloma model has been studied for testing the proliferative phase (granuloma formation). The extracts of seed and rind of $A$. subulatum showed significant \% inhibition of 46.08 and 51.32 , respectively. No signs of ulcerations were seen in either of the cases.

\section{Effect of $A$. subulatum extracts on formaldehyde-induced arthritis} in rats

The results of this experiment showed that $A$. subulatum rind extract on the $10^{\text {th }}$ day at $500 \mathrm{mg} / \mathrm{kg}$ dose level showed a significant reduction in paw edema, i.e., $75.86 \%$ as compared to the arthritic control group and these results were almost comparable with the standard drug (77.45\%). However, A. subulatum seed extract at $500 \mathrm{mg} / \mathrm{kg}$ dose level exhibited $71.12 \%$ reduction in paw diameter.

\section{In vitro parameters}

Effect of A. subulatum extracts on inhibition of albumin denaturation

In protein denaturation, proteins lose their tertiary structure and secondary structure by application of external stress or compound, such as strong acid or base, a concentrated inorganic salt, an organic solvent or heat. When studied, it was found effective in inhibiting heat-induced albumin denaturation. Maximum inhibition of $73 \%$ was observed at $500 \mu \mathrm{g} / \mathrm{ml}$ in A. subulatum rind extract. The standard anti-inflammation drug showed the maximum inhibition of $75 \%$ at the concentration of $100 \mu \mathrm{g} / \mathrm{ml}$ compared with control. 


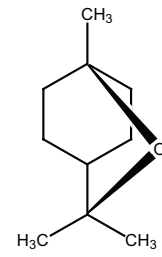

1,8-cineole

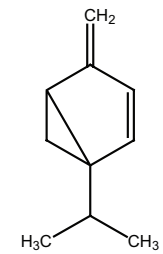

Sabinene

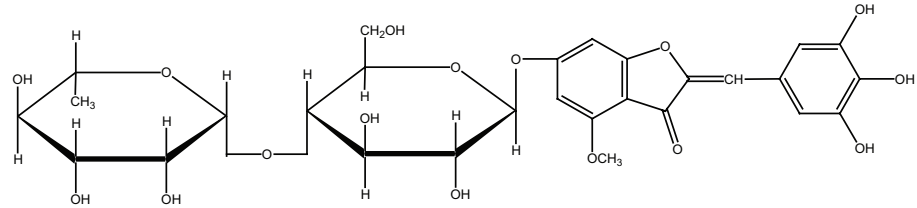

Subulin

Fig. 1: Structures of major phytoconstituents of $A$. subulatum

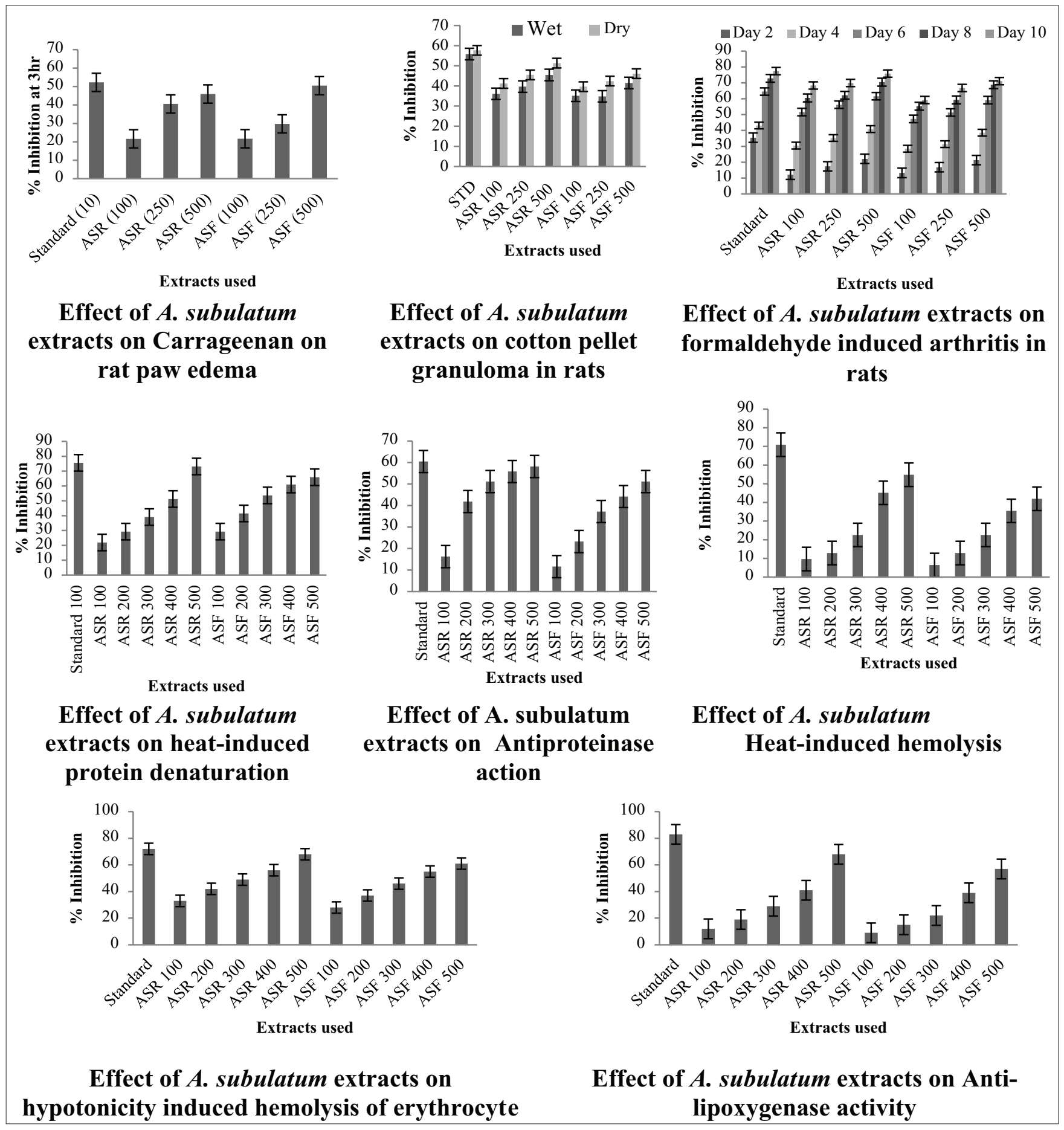

Fig. 2: Graphical presentation of various in vivo and in vitro parameters evaluated to check the anti-inflammatory activity of rind and fruit extracts of Amomum subulatum 
Effect of A. subulatum extracts on antiproteinase action

Neutrophils are known to be a rich source of serine proteinase and are localized at lysosomes. It was previously reported that leukocytes proteinase plays an important role in the development of tissue damage during inflammatory reactions and a significant level of protection was provided by proteinase inhibitors [18]. A. subulatum extracts exhibited significant antiproteinase activity at different concentrations. The rind extract showed maximum inhibition of $58 \%$ at $500 \mu \mathrm{g} / \mathrm{ml}$. The standard drug showed maximum inhibition of $60 \%$ at $100 \mu \mathrm{g} / \mathrm{ml}$

\section{Effect of $A$. subulatum extracts on membrane stabilization}

The human RBC membrane stabilization has been used as a method to study the in vitro anti-inflammatory activity because the erythrocyte membrane is analogous to the lysosomal membrane $[19,20]$ and its stabilization implies that the extract may well stabilize lysosomal membranes. Stabilization of the lysosomal membrane is important in limiting the inflammatory response by preventing the release of lysosomal constituents of activated neutrophil, such as bacterial enzymes and proteases, which causes further tissue inflammation and damage on extracellular release. The lysosomal enzymes released during inflammation produce various disorders. The extracellular activity of these enzymes is said to be related to acute or chronic inflammation. The nonsteroidal drugs act either by inhibiting these lysosomal enzymes or by stabilizing the lysosomal membrane [21].

\section{Effect of A. subulatum extracts on heat-induced hemolysis}

The extracts were effective in inhibiting the heat-induced hemolysis at different concentrations. The results showed that the rind extract of $A$. subulatum at concentration of 400 and $500 \mu \mathrm{g} / \mathrm{ml}$ protects significantly the erythrocyte membrane against lysis induced by heat. Standard drug $(100 \mu \mathrm{g} / \mathrm{ml})$ offered significant protection against the damaging effect of heat solution.

\section{Effect of A. subulatum extracts on hypotonicity-induced hemolysis}

The results showed that the rind extract of $A$. subulatum at a concentration range of $200-500 \mu \mathrm{g} / \mathrm{ml}$ protects significantly the erythrocyte membrane against lysis induced by hypotonic solution. The standard drug $(100 \mu \mathrm{g} / \mathrm{ml})$ offered significant protection against the damaging effect of hypotonic solution. At the concentration of $500 \mu \mathrm{g} / \mathrm{ml}$, it showed a maximum of $54 \%$ protection, whereas the standard drug $(100 \mu \mathrm{g} / \mathrm{ml})$ showed $70 \%$ inhibition of RBC hemolysis when compared with control.

\section{Effect of A. subulatum extracts on anti-lipoxygenase activity}

LOXs are sensitive to antioxidants and most of their action may consist of inhibition of lipid hydroperoxide formation due to scavenging of lipidoxy or lipid peroxy radicals formed in course of enzyme peroxidation. Extracts of $A$. subulatum seed and rind were tested for their potential against lipoxygenase activity at various dose levels ranging from 100 to $500 \mu \mathrm{g} / \mathrm{ml}$. From the result, the strongest inhibition was obtained by rind extract at a concentration of $500 \mu \mathrm{g} / \mathrm{ml}$. The standard drug showed $83 \%$ inhibition at a concentration of $100 \mu \mathrm{g} / \mathrm{ml}$.

The results obtained from our studies Fig. 2 on seed and rind extracts of $A$. subulatum have shown a potential anti-inflammatory activity. The extracts inhibited the lipoxygenase enzyme activity. This indicates that $A$. subulatum is more useful in studies of inflammation and can be explored in other related physiological studies, aging, and diseases such as cancer and neurological disorder.

\section{CONCLUSIONS}

In the present study, results indicate that the methanolic extracts of seed and rind of Amomum subulatum possess anti-inflammatory properties. These activities may be due to the strong occurrence of polyphenolic compounds such as flavonoids, tannins, terpenoids, steroids, and phenols. The extract fractions serve as free radical inhibitors or scavenger or acting possibly as primary oxidants and inhibited the heat-induced albumin denaturation, proteinase activity, and stabilized the RBCs membrane. The extracts also reduced the activity of lipoxygenase. The rind extract was found more effective as compared to seed extract. Purification of each bioactive compound is necessary and this purified form of the compound can be used which may show increased activity.

\section{ACKNOWLEDGMENT}

The author is thankful to Director, Govt. of N.C.T. of Delhi, Delhi Institute of Pharmaceutical Sciences and Research (DIPSAR), New Delhi, for providing infrastructure, facilities, and funds to carry out the present research work.

\section{AUTHORS' CONTRIBUTIONS}

The author herself has carried out the present study.

\section{CONFLICTS OF INTEREST}

There are no conflicts of interest concerning the present study

\section{AUTHORS' FUNDING}

Funds for the present study were provided by Govt. of N.C.T. of Delhi.

\section{REFERENCES}

1. Anonyms. Wealth of India, a Dictionary of Indian Raw Materials and Industrial Products. $1^{\text {st }}$ Supplement Series (Raw Materials). New Delhi: National Institute of Science Communication; 2004

2. Anonymous. Quality Standards of Indian Medicinal Plants. Vol. 3. New Delhi: Indian Council of Medical Research; 2005. p. 1-8.

3. Anonymous. Indian Herbal Pharmacopoeia. Vol. 1. Mumbai: Indian Drug Manufacturers Association; 2002. p. 1-10.

4. Rao CB, Rao TN, Suryaprakasam S. Cardamonin and alpinetin from the seeds of Amomum subulatum. Planta Med 1976;29:39139-42.

5. Nadkarni AK. In Indian Materia Medica (Dr. K.M. Nadkarni's). $3^{\text {rd }}$ ed. Mumbai, Maharashtra: Popular Prakashan Pvt. Ltd.; 1982. p. 40-3.

6. Jafri M, Farah A, Javed K, Singh S. Evaluation of the gastric antiulcerogenic effect of large cardamom (fruits of Amomum subulatum Roxb). J Ethnopharmacol 2001;75:89-94

7. Dhuley JN. Anti-oxidant effects of cinnamon (Cinnamomum verum) bark and greater cardamom (Amomum subulatum) seeds in rats fed a high-fat diet. Indian J Exp Biol 1999;37:238-42.

8. Kikuzaki H, Kawai Y, Nakatani NJ. 1,1-Diphenyl-2-picrylhydrazyl radical-scavenging active compounds from greater cardamom (Amomum subulatum Roxb.), Nutr Sci Vitaminol 2001;47:167-71.

9. Winter CA, Risley EA, Nuss GW. Carrageenin-induced edema in hind paw of the rat as an assay for anti-inflammatory drugs. Proc Soc Exp Biol Med 1962;111:544-7.

10. Winter CA, Porter CS. Effect of alterations in side-chain upon antiinflammatory and liver glycogen activities of hydrocortisone esters. J Am Pharm Sci 1957;46:515-9.

11. Brownlee G. Effect of deoxycortone and ascorbic acid on formaldehyde induced arthritis in normal and adrenalectomized rats. Lancet 1950;1:157-9.

12. Mizushima Y, Kobayashi M. Interaction of anti-inflammatory drugs with serum proteins, especially with some biologically active proteins. J Pharm Pharmacol 1968;20:169-73.

13. Sakat S, Juvekar AR, Gambhire MN. In vitro antioxidant and antiinflammatory activity of methanol extract of Oxalis corniculata Linn. Int J Pharm Pharmacol Sci 2010;2:146-55.

14. Oyedepo OO, Femurewa AJ. Anti-protease and membrane stabilizing activities of extracts of Fagra zanthoxiloides, Olax subscorpioides and Tetrapleura tetraptera. Int J Pharmacongn 1995;33:65-9.

15. Sadique J, Al-Rqobahs WA, Bughaith, EIGindi Ar. The bioactivity of certain medicinal plants on the stabilization of RBS membrane system. Fitoterapia 1989;60:525-32.

16. Shinde UA, Kulkarni KR, Phadke AS, Nair AM, Dikshit VJ, Saraf MN. Mast cell stabilizing and lipoxygenase inhibitory activity of Cedrus deodara (Roxb.) Loud. wood oil. Indian J Exp Biol 1999;37:258-61.

17. Azeem AK, Dilip C, Prasanth SS, Junise V, Shahima H. Antiinflammatory activity of the glandular extracts of Thunnus alalunga. 
Asia Pac J Med 2010;3:412-20

18. Das SN Chatterjee S. Long term toxicity study of ART-400. Indian Indg Med 1995;16:117-23.

19. Gandhidasan R, Thamaraichelvan A, Baburaj S. Anti inflammatory action of Lannea coromandelica by HRBC membrane stabilization. Fitoterapia 1991;62:81-3.
20. Shenoy S, Shwetha K, Prabhu K, Maradi R, Bairy KL, Shanbhag T. Evaluation of anti-inflammatory activity of Tephrosia purpurea in rats. Asian Pac J Trop Med 2010;3:193-5.

21. Vadivu R, Lakshmi KS. In vitro and in vivo anti-inflammatory activity of leaves of Symplocos cochinchinensis (Lour) Moore ssp Laurina. Bangladesh J Pharmacol 2008;3:121-4. 